\title{
Which Mobile Learning is More Suitable on Physics Learning in Indonesian High School?
}

\author{
https://doi.org/10.3991/ijes.v5i1.6494 \\ D. Sulisworo \\ Ahmad Dahlan University, Yogyakarta, Indonesia \\ dsw_uadeyahoo.com \\ L. Yunita \\ Ahmad Dahlan University, Yogyakarta, Indonesia \\ ylia47@yahoo.com \\ A. Komalasari \\ Ahmad Dahlan University, Yogyakarta, Indonesia \\ arifkomala@gmail.com
}

\begin{abstract}
The use of mobile learning tool has controversy in Indonesian schools. Some teachers feel that it would interfere with the learning process in the classroom, but at the same time teachers saw a lot of potential of mobile technology. The goal of this study is to observe secondary schools on facilitating students through the use of mobile learning. This research is descriptive qualitative evaluations on the assembling mobile learning in several secondary schools in several regions in Indonesia during 2014-2015. The results of this study indicate that some of the schools that have implemented mobile learning, there is a tendency that mobile learning was not in a planned and structured as a school program. Two things are important to solve this condition are the availability of government policy and increase literacy teachers in managing mobile learning application.
\end{abstract}

Index Terms - mobile learning, education, teaching and learning, learning strategy, mobile technology.

\section{Introduction}

Indonesian people has been ready to use mobile technology, either for social or technology interest [1]. However, another research in 2013 found a paradox in schools in which students have a good ICT literacy, but the school did not support its implementation in the learning process sufficiently [2]. In other word, the use of smart phone as the instrument of mobile learning in school became a controversy. On one hand, the school forbade students to use mobile phone because it could disturb learning process; on the other hand, the teachers saw some benefits of mobile technology [3][4][5].

The positive point comes up in the latest years is that there is significant change on teachers' awareness to make use of ICT in mobile learning. This phenomenon is regarded as part of implication of mobile and wireless technology development growing rapidly these days [4][6]. The technology becomes cheaper in price, higher in performance, and smaller in size. Those things make teachers realized that digital technolo- 
gy offers alternative chance of learning in different way; including the relationship between teacher- student, teacher - teacher, student- student and student-material [7].

This research intended to describe the development of high schools in Indonesia to facilitate students' learning through mobile learning. Hopefully, the result might give considerable policies to strengthen the operating learning system by which students are able to reach learning competencies optimally.

\section{Literature Review}

\subsection{The Trend of Mobile Technology Penetration in Indonesia}

The use of ICT in learning process in Indonesia can be viewed in survey results [8] related to global digital statistics from the latest two years $(2014,2015)$. Although generally the penetration of internet in Indonesia just touched $28 \%$ in 2015 , but it shows significant progress compared to the attainment $15 \%$ in 2014 . The developing simultaneous growths in many sectors are predicted to boost its penetration in the future.

In 2015, users spent 5.1 hours of notebook, and 3.2 hours through mobile devices to access internet. It depicts a progressive trend to use mobile devices more, since in 2014 time of using internet through notebook was 5.5 hours and through mobile devices was 2.5 hours. Therefore, there is an increase 0.7 hour to access internet using mobile devices or increases $28 \%$ in. It is obviously a relatively high number of shifting from laptop to mobile devices; although in the global level, Indonesia declined from the $3 \mathrm{rd}$ rank of 25 countries to the 7 th rank of 31 countries in 2015. Meanwhile, from the category of mobile share on the web traffic in 2015 , Indonesia contributed $50 \%$ in the 4 th rank of 31 countries with the average global percentage was $33 \%$. The increasing trend of mobile devices can be perceived as opportunity of school learning. It might inspire teachers to create learning activities using mobile devices to help students to reach the competency optimally.

\subsection{Definition of Mobile Learning}

Mobile learning (m-learning) is the part of electronic learning or e-learning which gives broader opportunity in mobile mode, and better capabilities for students learning. The definition may distinct m-learning clearly from e-learning in terms of student mobility as learners [5][9]. Students can learn wherever they are [3][10]. Mobile learning perspective can be classified into four, they are techno-centric, e-learning focus, formal education instrument and student-centered learning [11][12][13]. Nowadays, technology empowerment at schools is used to ensure the implementation of effective learning with new opportunities and to encourage better learning performance [7][9][10]. 


\section{$3 \quad$ Method}

This research applied descriptive qualitative evaluation research. The researcher observed toward the implementation of mobile learning for the 10 senior high schools at 8 diffrent districts in Indonesia during 2015 at grade 1 or 2 for Physics subject as mentioned on table 1 .

The observed variables, the learning strategies for each district is presented on table 2.

Table 1. Subject Number for each district

\begin{tabular}{|c|c|c|c|c|c|}
\hline \multirow{2}{*}{ No } & \multirow{2}{*}{ Place/ District } & \multirow{2}{*}{ School No. } & \multicolumn{3}{|c|}{ Number of Students } \\
\hline & & & $M$ & $F$ & Total \\
\hline \multirow{2}{*}{1} & \multirow{2}{*}{ Yogyakarta } & 1 & 25 & 34 & 59 \\
\hline & & 2 & 16 & 12 & 28 \\
\hline \multirow{2}{*}{2} & \multirow{2}{*}{ Bantul } & 1 & 20 & 21 & 41 \\
\hline & & 2 & 31 & 33 & 64 \\
\hline 3 & Temanggung & 1 & 42 & 18 & 60 \\
\hline 4 & Purworejo & 1 & 26 & 4 & 30 \\
\hline 5 & Magelang & 1 & 17 & 12 & 29 \\
\hline 6 & Cilacap & 1 & 27 & 25 & 52 \\
\hline 7 & Bima & 1 & 18 & 17 & 35 \\
\hline \multirow[t]{2}{*}{8} & Tidore & 1 & 15 & 17 & 32 \\
\hline & Total & 10 & 237 & 193 & 430 \\
\hline
\end{tabular}

Table 2. Observed variable

\begin{tabular}{cllll}
\hline \multirow{2}{*}{ No } & Place/ District & $\begin{array}{c}\text { Types of Mobile } \\
\text { Application }\end{array}$ & Observable Variables & Learning strategies \\
\hline \multirow{2}{*}{1} & Yogyakarta & Self-developed & $\begin{array}{l}\text { Thinking Skill, Cooperation, Self- Personalized Learning } \\
\text { esteem } \\
\text { Environment }\end{array}$ \\
\cline { 3 - 5 } 2 & Bantul & Moodle & Achievement & 7E \\
\cline { 3 - 5 } & Facebook & Understanding & Jigsaw Learning \\
\hline 3 & Temanggung & Self-developed & Interest, Achievement & STAD \\
\hline 4 & Purworejo & Self-developed & Activeness, Achievement & Drill \& Practice \\
\hline 5 & Magelang & Edmodo & Interest, Activeness, Achievement & PDEODE \\
\hline 6 & Cilacap & Edmodo & Conceptual Understanding, & Problem Based Learning \\
\hline 7 & Bima & Path & Thinking Skill, Motivation & \\
\hline 8 & Tidore & Facebook & Achievement, Motivation & Project based learning \\
\hline
\end{tabular}


The observation aspects to be examined in this research were types of mobile application used in learning process, reasons of using mobile learning, considerable variables in applying mobile learning, result and obstacles found in the application of mobile learning, types of multimedia used in learning, and learning strategies employed.

\section{$4 \quad$ Result and Discussion}

\subsection{Types of Mobile Application}

The mobile applications used by the students were Moodle, Edmodo, Path, Facebook and self-developed application. Moodle is learning management system which has complete features. This application can be used in notebooks, tablets and smartphone. However, these rich features should be perceived from two sides; namely the feasibility of highly-flexible interactions between teacher and students with various modes; but also the complexity of application usage for teachers whose lowlimited Moodle literacy level. The features can be used for Journal, Chats and Forums, Graded Quizzes, Lessons, Book, Wikis, Lightbox galleries, Voicethread, Add Gadgets and RSS feeds using HTML, Use the Project Format, dan Collaborate in Realtime.

Edmodo is learning management system which involves parents as the monitor of students learning activities. This application can be used in notebook and other smart devices under the bases of social-network. Yes, it is less complete than Moodle, but it is relatively adequate for a certain learning objectives. It provides some features such as Polling, Gradebook, Quiz, File and Links, Library, Assignment, Award Badge, and Parent Code. It really suits for students who still need parents' support. Yet, in senior high school level, they rarely used Parent Code application.

Path is a social network which can be used to share pictures and message (social networking-enable photo sharing and messaging). In the beginning, this application is indeed not used for learning or education in general, but it is widely utilized to reach social networks to disseminate information. Since the number of youngsters using this application is growing by numbers, it gives inspiration to apply it for learning. Although assessment or grading in learning activities cannot be done automatically through system, the users can use it comfortably through messaging, still.

Facebook is the most frequently used application in social media. It is relatively same as Path but there is a feature which does not exist in Path, namely Page. This feature enables users to share their friends certain themes. Facebook also provides facilities for chatting, and flexible document sharing.

Self-developed application is designed by teachers themselves to adjust to certain specific learning strategies appropriately. Nevertheless, having been observed from the existing modules, this learning management system is generally adopted from modules in Moodle. The advantage of this application is more customized by teacher. But it would be problematic for teachers who do not have sufficient programming experience. 


\subsection{The reasons of using mobile learning}

There were some reasons which are explained by teachers in using mobile learning in school. First is the necessity of time-learning flexibility. It mostly happened in vocational schools in which most students spend their time at practicing field, thus they cannot follow the lesson at school. Consequently, they followed the class through online. The competencies expected from the mobile learning constitute a part of the whole competences for one semester.

Second, it gave opportunity to students to repeat the materials unrestrictedly. In such schools, this mobile learning was used simultaneously with conventional school learning more likely as blended learning. The learning lessons and tasks were available online. Students can learn by themselves out of classroom. Slightly different from first reason, it played more as adjoining learning resources for students. They could learn over again materials they have learnt at classroom.

From both reason, it seemed that the teachers make use of learning mobile just for the sake of solving the problems of classroom learning inadequacy. It was not used as a well-structured planned learning activity in school. The teachers individually, not by system, made an initiative to apply mobile learning for their personal satisfaction. It was possibly caused by the absence of national policy to push schools to implement online learning. The government possibly was unwilling to oblige the policy because they consider about the school inability to sufficient the infrastructure, and also the teachers' literacy in operating mobile learning. If the government did not gives strategic policy related to the use of mobile learning application, we cannot hope much about the quality of national education development. Students tended to use their mobile activities mostly as means of social media as displayed in global digital statistic data (Kemp, 2015)

\subsection{Observable Variables}

In the research setting, generally the dependent observable variable was the level of material understanding. It was measured by giving some tests related to the material. The test items were made by considering taxonomy Bloom based on the expected level, item difficulty test, and item discrimination test. The findings showed that mobile learning could improve student's ability in understanding the material significantly in all schools.

Of course the result could not be used automatically for final justification, because it is quasi- experiment research. It means that there were a number of influencing but unobservable variables. It can be seen from the coefficient determination score approximately 0.60 in all subject schools. Those factors were a number of students taking extra courses out of school and the length of time being allocated by students to access online materials out of schools. Nevertheless, it can be said still that mobile learning offered opportunities for students in understanding the materials. 


\subsection{Learning strategies}

Based on the research, the learning strategies practiced in blended learning of students' interaction with the materials and exercises provided online. It is seen from the learning steps prepared by the teacher in lesson plan. Although some mobile learning application Whereas in some mobile learning application supplied various types of features, there was a strong tendency where the most frequently used features were lesson provider, discussion (synchronous/ asynchronous), exercises and materialrelated tests. Such learning environment was insufficient to stimulate self-directed learning among students. Students did the learning online just due to teacher's instruction. The fact strengthened the researcher's hypothesis that there should be affirmative policy from the authority to make use of mobile technology advancement in learning effectively and efficiently.

\section{Conclusion}

In national level, the penetration of mobile technology in Indonesia has increased from many aspects. Unfortunately, this condition was not optimally utilized optimally yet to improve students' learning competence. Some schools that have applied mobile learning tended not to design it as a well-planned and structured school program yet. As a result, they could not get much benefit from the advances of mobile learning technology effectively. Two important considerable issues to better the condition here were the presence of government's affirmative policy, and promotion of teachers' literacy in managing mobile learning application.

\section{Acknowledgment}

This research was funded by Directorate General of Higher Education, Ministry of Research, Technology, and Higher Education, Indonesia under postgraduate research grant for year 2014-2015

\section{$7 \quad$ References}

[1] D. Sulisworo, "The Social Readiness to Implement Mobile Learning in Indonesia," International Conference on Culture, Communication and Multimedia Technology (pp. 387391). Yogyakarta: UAD, 2012.

[2] D. Sulisworo, "Conceptual Model Identification of Personal Learning Environment". Innovation and Development in Teaching and Learning (pp. 37-41). Perak, Malaysia: UMM, 2014.

[3] H. Mohammad, A. Fayyoumi \& O. AlShathry, "Do We Have to Prohibit the Use of Mobile Phones in Classrooms?" International Journal of Interactive Mobile Technology, vol. 9, no. 2, pp. 54-57, 2015. https://doi.org/10.3991/ijim.v9i2.4394 
[4] D. Sulisworo, "The Paradox on IT Literacy and Science's Learning Achievement in Secondary School”. Internasional Journal of Evaluation and Research in Education, vol. 2, no. 4, pp. 149-152, 2013.

[5] H. M. Tal \& M. Gross, "Teaching Sustainability via Smartphone-Enhanced Experiential Learning in a Botanical Garden," International Journal of Interactive Mobile Technology, vol 8, no. 1, pp. 10-15, 2014. https://doi.org/10.3991/ijim.v8i1.3441

[6] M. Alqahtani, \& H. Mohammad, "Mobile Applications' Impact on Student Performance and Satisfaction," TOJET: The Turkish Online Journal of Educational Technology, vol. 14, no. 4, pp. 102-112, 2015.

[7] M. E. Babiker, "For Effective Use of Multimedia in Education, Teachers Must Develop their Own Educational Multimedia Applications," TOJET: The Turkish Online Journal of Educational Technology, vol. 14, no. 4, pp. 62-68, 2015.

[8] S. Kemp. Digital, Social \& Mobile Worldwide in 2015. Retrieved on November 17, 2015, from We Are Social: http://wearesocial.net

[9] P. Thinley, J. Reye \& S. Geva, "Tablets (iPad) for M-Learning in the Context of Social Constructivism to Institute an Effective Learning Environment". International Journal of Interactive Mobile Technology, vol. 8, no. 1, pp. 16-20, 2014. https://doi.org/10.3991/ ijim.v8i1.3452

[10] H.S. Ebrahim, K. Ezzadeen \& A.K, Alhazmi. “Acquiring Knowledge through Mobile Applications”. International Journal of Interactive Mobile Technology, vol. 9, no. 3, pp. 7174, 2015. https://doi.org/10.3991/ijim.v9i3.4495

[11] C.-H. Chen, S.-H. Chen, G.-J. Hwang \& T.-C. Yang, "Factors influencing teachers' adoption of a ubiquitous technology application in supporting teacher performance," International Journal of Mobile Learning and Organisation, vol. 4, no. 1, pp. 39-54, 2010. https://doi.org/10.1504/IJMLO.2010.029953

[12] A. Crampton, A. T. Ragusa \& H. Cavanagh, "Cross-discipline investigation of the relationship between academic performance and online resource access by distance education students," Research in Learning Technology, vol. 20, pp. 1-13, 2012. https://doi.org/10.3402/rlt.v20i0.14430

[13] S. M. Paterson, "Online Learning Communities: Motivational Factors for Success," International Journal of Recent Contributions from Engineering, Science \& IT, vol. 2, no. 2, pp. 6-12, 2014. https://doi.org/10.3991/ijes.v2i2.3812

\section{Authors}

D. Sulisworo has expertise on educational technology especially on mobile learning, learning strategy, and learning innovation. His home base is at Graduate Program of Ahmad Dahlan University, J1. Pramuka No. 42, Yogyakarta 55161, Indonesia (email: dwi.sulisworo@uad.ac.id).

L. Yunita is alumnae of Graduate Program, Ahmad Dahlan University. She is also a physics teacher at vocational high school in Cilacap, Indonesia. (e-mail: ylia47@yahoo.com).

A. Komalasari is alumnae of Graduate Program, Ahmad Dahlan University. She is also a physics teacher at vocational high school in Purworejo, Indonesia. (e-mail: arifkomala@gmail.com)

Article submitted 05 December 2016. Published as resubmitted by the authors 21 January 2017. 